シンポシウム -1

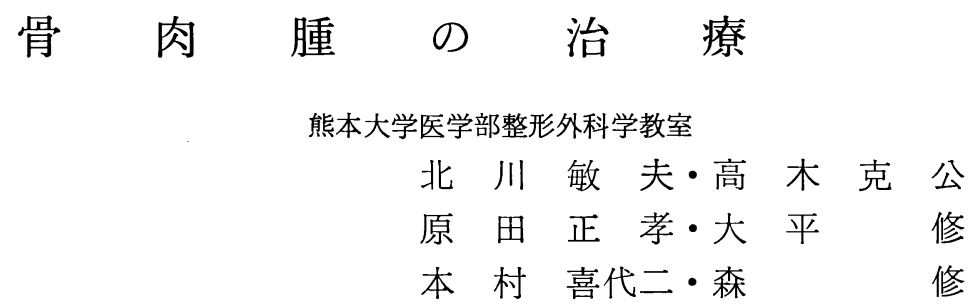

\title{
Treatment of Osteosarcoma
}

by

\section{T. Kitagawa K. Takagi M. Harada \\ O. Ohira K. Motomura and O. Mori}

Department of Orthopedic Surgery,

Kumamoto University Medical School, Kumamoto

\footnotetext{
Our patients with osteosarcoma are divided into 3 groups according to the method of treatment.

Group 1: In the 18 years between 1955 and 1972, immediate surgery with or without chemotherapy was performed in 26 patients. Five-year survival rate of group 1 was $19 \%$.

Group 2: In the 6 years between 1973 and 1978, 10 patients with osteosarcoma received intraarterial continous infusion of drug. All patients underwent delayed surgery following intraarterial continous infusion.

It seems that result of group 2 is better than that of group 1.

Group 3: Since 1978, 1 patient with osteosarcoma receives high dose of methotre -xate following surgery.
}

教室における骨肉腫の治療法の変遷は大きく分けて III期に分たれる（表 1). 第I 期は 1955 年から 1972 年に至る 18 年間で, 乙の間の症例は 27 症例である. この時期では最初は骨肉腫の疑があると, Biopsy を 行ない, 病理組織学的に診断を得て, 日を改めて切断 等の根治手術を行なった. その後まむなく，骨肉腫の 疑があると, 腫瘍近位部に二重止血帯を装用, 腫瘍部

\section{表 1}

I 期 1954 年 1972 年

主として早期根治手術群 (系統的化学療法治し)

(マイトマイシン灌流 3 例も含む)

III 期 1973 年〜1978 年

制癌剂の持続動脈注入後根治手術群 主要楽剤マイトマイシン

（併用薬剂 アドリアマイシン）

III 期 1979 年以降

$$
\text { メソトレキセート大量療法 }
$$

より組織片を採取, 病理検査室に frozen section に て診断を依頼, その間手術室に待期し, 組織診断にて 骨肉腫の診断が確定すると, その場で直ちに切断等の 根治手術を行なった. 術前, 術後の化学療法や放射線 療法に関しては症例により異なり，一定した方式はな かった. なおこの期間にマイトマイシンCによる局所 灌流を行なった症例が 3 症例ある. 灌流に使用した薬 剤はマイトマイシンCで, $0.8 \mathrm{mg} / \mathrm{kg}$ を 45 分間行な った. 然しての局所還流を行なった症例はすべて根治 手術後 1 年以内に死亡した. 乙の期間における 5 年 以上生存者は 5 名であるが, その中で 2 名はごく初期 の症例で, まず Biopsy を行ない，日を改めて切断 した症例である.この 2 例は骨肉腫ではあるが, 比較 的悪性度の低いあのであったのであろうと考えられ る. 第 II 期は 1973 年から 1978 年に至る 6 年間でこの 間の症例は 10 症例である（表 2 ）。乙の期間では骨肉 
表 2

\begin{tabular}{|c|c|c|c|c|c|c|c|c|}
\hline 症例 & 年令 & 性 & 組織像 & 期間 & 使用薬剂及び量 & 併 用 薬 剂 & 副作用 & 転 \\
\hline $\begin{array}{l}1 \\
2 \\
3 \\
4 \\
5 \\
6 \\
7 \\
8\end{array}$ & $\begin{array}{l}12 \\
12 \\
15 \\
15 \\
19 \\
13 \\
12 \\
18\end{array}$ & $\begin{array}{l}\text { 女 } \\
\text { 男 } \\
\text { 女 } \\
\text { 女 } \\
\text { 男 } \\
\text { 男 } \\
\text { 女 } \\
\text { 男 }\end{array}$ & $\begin{array}{c}\text { 溶骨型 } \\
\text { 硬化型 } \\
\prime \prime \\
\text { " } \\
\text { 溶骨型 } \\
\text { 硬化型 } \\
\text { " } \\
\text { 硬化型 } \\
\text { 硬化型 } \\
\text { 硬化型 }\end{array}$ & $\begin{array}{c}14 \text { 日 } \\
21 \text { 日 } \\
3 \text { 日 } \\
14 \text { 日 } \\
10 \text { 日 } \\
10 \text { 日 } \\
10 \text { 日 } \\
29 \text { 日 }\end{array}$ & $\begin{array}{l}\text { Mitomycin } 28 \mathrm{mg} \\
\text { Mitomycin } 40 \mathrm{mg} \\
\text { Endoxan } 600 \mathrm{mg} \\
\text { Mitomycin } 30 \mathrm{mg} \\
\text { Endoxan } 1600 \mathrm{mg} \\
\text { Mitomycin } 28 \mathrm{mg} \\
\text { Mitomycin } 20 \mathrm{mg} \\
\text { Mitomycin } 74 \mathrm{mg} \\
\text { Esquinon } 10 \mathrm{mg} \\
\text { Mitomycin } 80 \mathrm{mg} \\
\text { Mitomycin } 76 \mathrm{mg} \\
\text { Adriamycin } 30 \mathrm{mg}\end{array}$ & 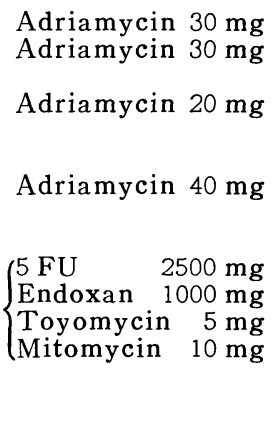 & $\begin{array}{l}\text { 感染, } \\
\text { 㽷毒症 }\end{array}$ & $\begin{array}{l}\text { 生( } 3 \text { 年 } 7 \text { 力月) } \\
\text { 生 ( } 2 \text { 年 } 7 \text { 力月) } \\
\text { 死 }(2 \text { 年 } 3 \text { 力月) } \\
\text { 死 }(4 \text { 力 }) \\
\text { 生 }(6 \text { 年) } \\
\text { 生 }(5 \text { 年 } 7 \text { 力月) } \\
\text { 生 }(4 \text { 年10 力月) } \\
\text { 死 }(3 \text { 力月) }\end{array}$ \\
\hline
\end{tabular}

表 5

$\begin{array}{lll}\text { Biopsy } & \text { Krterial continual infusion } & \text { Kumamoto Univ. } 1979\end{array}$

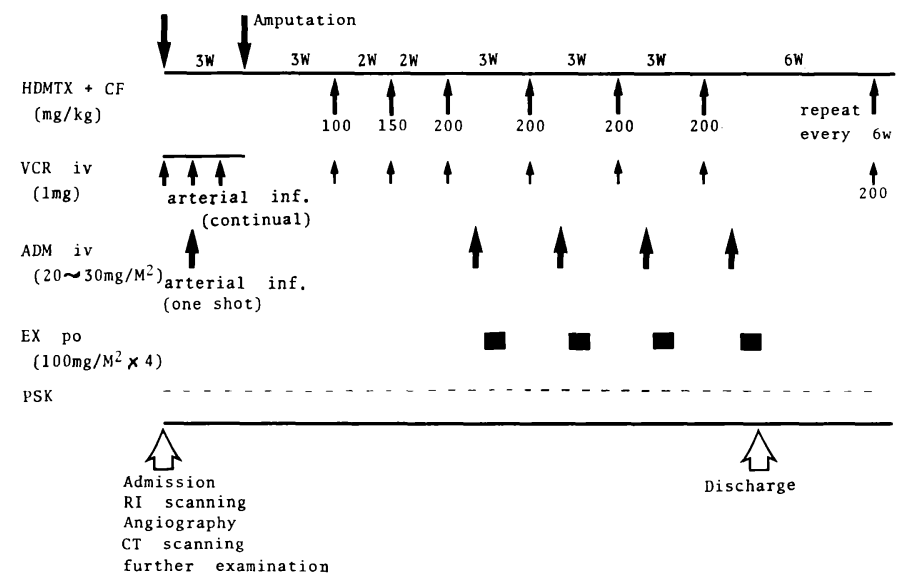

腫の疑のあると，まず制癌剂の持続動脈注射を行な い, 持続動注間に Biopsyを行なって病理組織学的 診断を得, 約 3 週の持続動脈注射後に切断等の根治手 術を行なった．持続動脈注射に用いた薬剤は主として マイトマイシンCで, 期間は大略 3 週, 薬剂量は 30 〜 $40 \mathrm{mg}$ であった. なおアドリアマイシンの投与を 併用した症例もある. 本期間中の 5 年経過例は 5 名で あるが，そのうち生存者は 2 名である. 第 I 期の症例 より好結果が期待出来そうである. 第期 は 1978 年 以降で, メリトレキセートの大量療法を主としたもの である. 本方法については表 3 にシェマーで述べてあ る.

骨肉腫の疑があると，まずビンクリスチンの持続動
脈注射を 3 週ほど行なう. この間にアドリアマイシン を静脈内，または動脈内に one shot で注射する. 持続動注終了後, 病理組織学的診断を得て切断等の根 治手術を行なう. 手術より 3 週後にメソトレキセート の投与を行なう. 最初は $100 \mathrm{mg} / \mathrm{kg} 2$ 週後 $150 \mathrm{~m} / \mathrm{g}$ $\mathrm{kg}$, 次 2 週後 $200 \mathrm{mg} / \mathrm{kg}$ となり, 以下 3 週でとに $200 \mathrm{mg} / \mathrm{kg}$ を 3 回行なう. その後 6 週後に $200 \mathrm{mg} /$ $\mathrm{kg}$ を投与し, 大体手術後 1 年半行なう. その外術後 8 週よりエンドキサンを 3 週おきに 4 回投与する. ま た入院時より PSK を投与する. メソトレキセートの 大量療法の原理は今更述べることでもないが，一度述 べる.メソトレキセートは DHF (dihydrofolate) を THF (Tetrahydrofolate) に還元するととを阻止 


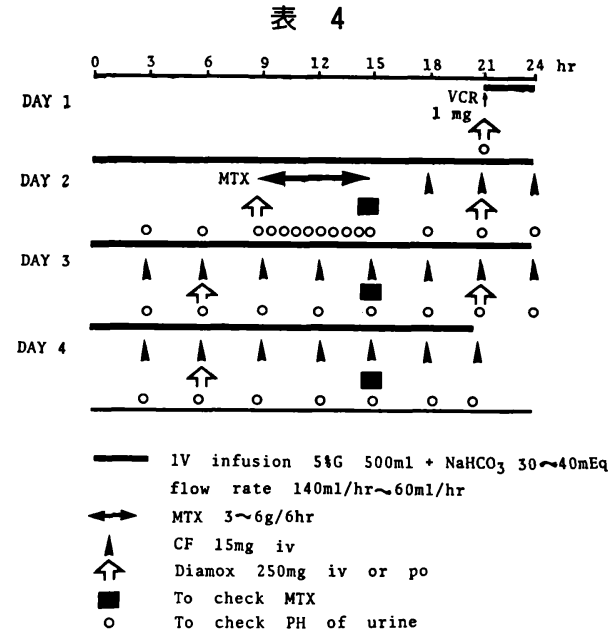

し，てれにより，DNA プリン体，蛋白の合成を抑制 する. CF (citrovorum factor) はメソトレキセー トにより産生が阻止された D. N. A. 合成を 回復さ せる. このC F は低濃度では正常細胞に作用するが, 腫瘍細胞には作用せず，乙のため，腫瘍細胞のみが死 滅するわけである. 実際に行なう要領は表 4 亿示す如 くである. 本療法を行なうに際しては尿の $\mathrm{PH}$ を 7.5 以上に保っておくことが重要である．またメントレキ セートの血中濃度測定を行ない，48 時間後のメソト レキセートの濃度 $2 \times 10^{-7} \mathrm{M}$ 以上では $\mathrm{C} \mathrm{F}$ の充分量 を長期に投与しなければいけない，実際には尿のアル カリ化を保つため $\mathrm{NaHCO}_{3}$ を $30 \sim 40 \mathrm{mEq}$ を投与 している. 利尿剂 diamox あ投与している. 頻回に 尿の $\mathrm{PH}$ を計り，危険防止に努めなければならな い. 現在このメソトレキセートの大量療法は 1 例に行 なったのみであり，乙の療法に関する見解は述べな い. 以上が当教室における骨肉腫の治療法の変遷之, その成績である．現在骨肉腫の化学療法剤の主なもの はアドリアマイシン，メソトレキセートなどである が，一般に腫瘍の制癌剂に対する感受性は個々の腫瘍 によって異なる場合ああり，制癌剤の感受性テストの 問題は重要である．制癌剤の感受性テストについては 現今 SDI 法, INAS 法, 培養によるマイクロコロニ 一形成阻止試験などある．然し現段階ではいずれの方 法も完全とは言いがたい，われわれは殆んぞすべての 制癌剂が D. N. A. 合成を阻害することから，未処 置の腫瘍細胞と，種々の制癌剤を作用させた時の腫瘍 細胞との D. N. A. 量を求めるととにより制癌剂の

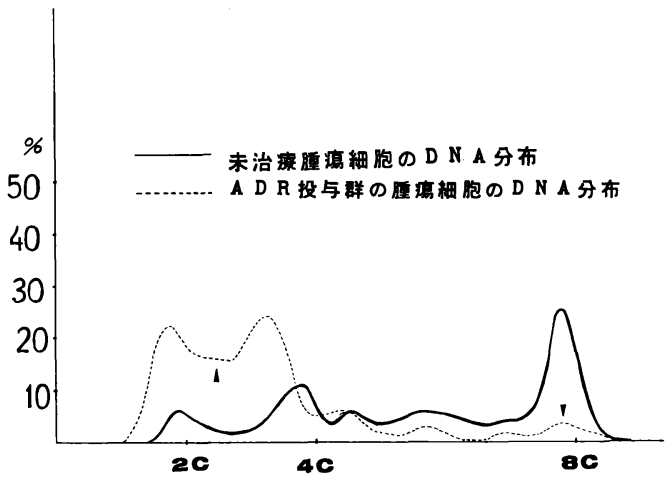

図 1

感受性が分りはしないかと考えた，そこで walker's carcinosarcoma 及び臨床例について Feulgen 染 色による D. N. A. の染色を行ない，その螢光を二 コン顕微螢光法により測定し D. N. A. 量を求めた. Donryu rat に継代移植してある walker's carcinosarcoma にエンドキサン，ブレオマイシン， 5 $\mathrm{FU}$, アドリアマイシン, マイトマイシンの LD 50 の $1 / 2$ 量を 連続 4 日腹腔内に注入， 7 日後に腫瘍を摘 出, 未処置の腫瘍之共に二コン顕微螢光法で腫瘍細胞 の D. N. A. 量を測定した. 図 1 はアドリアマイシ ン投与のあのであるが， $8 \mathrm{C}$ のピークが著明に抑制さ れているのが分る. また図 2 はブレオマイシン投与の あのであるが，アドリアマイシン同様 $8 \mathrm{C}$ のピークが 抑制されていた. 他のエンドキサン， $5 \mathrm{FU}$ ， マイト マイシンは未処置のものとあまり差はなかった. かか る点より本腫瘍にはアドリアマイシン, ブレオマイシ ンが効果があるのではないかと考えられる. 然し, 制 癌剂は正常細胞をも傷害することが多いので, 出来る だけ正常細胞を傷害しない薬剂が 理想的なわけであ

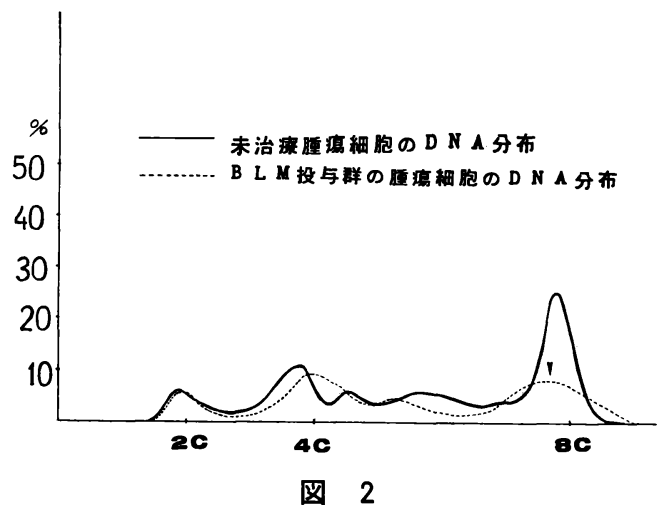

図 2 
表 5 制癌剂使用時のリンパ球の Growth

Fraction* (PHA 刺激後 $72 \mathrm{hr}$ で計測)

* DNA 合成期にある細胞 $\left(S+G_{2} \cdot M\right)$

\begin{tabular}{|l|l|}
\hline コントロール & $7.8 \%$ \\
PHA のみ & 47.1 \\
MMC 使用群 & 29.8 \\
EnX " " " & 35.9 \\
ADR* " " " & 22.0 \\
5FU " " " & 38.2 \\
BLM " " " & 45.2 \\
\hline
\end{tabular}

* ADR では 2C (Diploid) 以下む $22 \%$ 存在し た

る. そこで上記の各制癌剤の正常細胞の傷害の程度を 検索した. 正常細胞の中の免度担当細胞であるリンパ 球が各制癌剤によりどの程度 D. N. A. 合成が阻害 されるかを検索した. 表 5 に示す如くGrouth Fvaction すなわち, D. N. A. 合成期にある細胞は PHA で刺激したリンパ球ではアドリアマイシンを作用させ た時に最も低くなる．ブレオマイシンを作用させた時 PHA 刺激のみに比べて僅かに低下するのみである. かかる点よりすれば，ブレオマイシンの方が，アドリ アマイシンより, よい上考えられる. 次に実際の臨床 例の Giant-cell tumor（組織学的には II 度の悪性 度）の上述の方法による制癌剤の感受性は表 6 の如く である. $8 \mathrm{C}$ の抑制度よりみると, アドリアマイシ ン, マイトマイシン，5FU などは勃果があるように 思われる. メソトレキセートは本测定ではかえって $8 \mathrm{C}$ が増大している. 以上われわれの行なっている制 癌剂の感受性テストに関する研究の一端を述べたが, 本研究は未だ緒についたばかりであり，完成されたす のではない.

\section{結語}

教室における過去 25 年間の骨肉腫の治療方法の変 遷と，その成績について述べた. また，われわれの制 癌剂の感受性テストに関する研究の一端を述べた，優 秀な制癌剂の登場が骨肉腫になやむ若人を救う唯一の 方法である。

\section{文献}

1）赤星義彦：骨肉腫に対する術前化学療法. と に局所動脈内插管投与法の意義. 小児がん，13： 57-60, 1979.

2）藤本孟男：制癌剤治療について，小児がん， 13: 103-106, 1979.

\section{発 言東京医科歯科大学 古屋光太郎}

骨肉腫に対する放射線開創炤射療法の結果 は次の 通りです. 4 例にリニアック 6000〜9000 rad を 5FU, BUdR 点滴静注下で照射しましたが，炤射後の 骨壊死, 変形, 病的骨折, 脚長差の問題が残り結局 2 $\sim 3$ 年後に 4 例中 3 例に切断術を施行しております. 切断肢での肉眼的, 組織学的検索でほぼ全例で腫瘍組 織の壊死, 細胞の消失を認め局所はよく control さ れており，しかも開創せずに $10000 \mathrm{rad}$ 照射した症 例と異なり, 神経, 血管, 筋肉が正常に近い状態に保 たれているととを知りました. しかし根治的な radiation の適応は，ほぼ成長の終了した青年あるいは 成人に限られると思う。なお，免疫効果は 4 例中 3 例 に肺転移を認めていることより余り期待出来ないもの と考えます.

表 6 Giant Cell Tumor (Grade 11) に対する感受性検查 $\alpha=$ D. N. A. content of Tumor Cell

\begin{tabular}{|l|c|c|c|c|c|c|c|}
\hline & $2 \mathrm{C}<\alpha$ & $2 \mathrm{C}$ & $2 \mathrm{C}<\alpha<4 \mathrm{C}$ & $4 \mathrm{C}$ & $4 \mathrm{C}<\alpha<8 \mathrm{C}$ & $8 \mathrm{C} \leqq \alpha$ & Stem line \\
\hline בント口- (無処置) & 0 & 31.4 & 29.4 & 5.9 & 25.5 & 7.8 & $2 \mathrm{C}$ \\
Adriamycine & 18.0 & 26.0 & 34.0 & 18.0 & 4.0 & 0 & $2 \mathrm{C}$ \\
Mitomycine & 20.7 & 15.1 & 41.5 & 5.7 & 13.2 & 3.8 & $2 \mathrm{C}$ \\
Methotrexate & 0 & 6.1 & 6.1 & 10.2 & 36.7 & 40.8 & $8 \mathrm{C}$ \\
5-Fluorouracil & 30.0 & 18.0 & 22.0 & 14.0 & 12.0 & 4.0 & $2 \mathrm{C}$ \\
Picibanil & 4.7 & 11.5 & 25.0 & 15.4 & 30.7 & 7.7 & $4 \mathrm{C}$ \\
Endoxan & 2.1 & 6.4 & 23.4 & 14.9 & 38.3 & 14.9 & $4 \mathrm{C}$ \\
Esquinon & 10.4 & 6.3 & 35.4 & 6.3 & 31.2 & 10.4 & $2 \mathrm{C}$ \\
\hline
\end{tabular}

